\title{
PROTECTED AREAS - CHANCE OR BARRIER FOR FOOD QUALITY IN CASE OF AGRICULTURE IN POLAND
}

\author{
Anna Iwacewicz, Orlowska ${ }^{1}$
}

\begin{abstract}
Summary
The main aim of this paper is to present the relation between the state of the natural environment and the food quality produced on a given area. The two groups of analysed business activities are ecological farms and eco-friendly food processing plants. In the work, the author conducted a comparative analysis of the Polish voivodships with large and small shares of valuable natural areas in the total area of the voivodship in relation to the ecological farms and eco-friendly food processing plants.
\end{abstract}

Key words: ecological food processing, food quality, protected areas, organic farms.

JEL: $Q 15, Q 18$

\section{Introduction}

The problem discussed in this paper is poor quality of food. The main aim of the research was verification of the hypothesis that the quality of food is better if the food is produced in regions with a large scale of protected areas. The paper includes an analysis of the effect of the natural environment on the quality of food produced on a given area. There are 2 groups of entities affecting food quality: organic farms and eco-friendly food processing farms. For the first group, increasing demand for high quality food will determine the rise in quantities of sustainable agriculture farms offering organic products. Organic agriculture farms specialize in high quality food production. Eco-friendly food processing plants are the second group of entities affecting the quality of foodstuffs. Local food processing plants that use high quality raw material contribute to the high quality of final foodstuffs (Ministry of Agriculture and Rural Development, 2011).

The paper presents a comparative analysis of the voivodships in Poland with large and small participation of protected areas in the general area of the voivodship in relation to organic farms and eco-friendly food processing plants.

1 Anna Iwacewicz Orlowska, Ph.D., University of Finance and Management in Bialystok, Ciepla Street no. 40, 15-472 Bialystok, Poland, Phone: +48 692 464884, E-mail: anna.orlowska@wsfiz.edu.pl

EP 2014 (61) 1 (115-126) 


\section{Paper goals}

Besides the price, food quality is more and more often one of the basic factors affecting choice and the purchase of foodstuff. Substantial changes distinguish the $20^{\text {th }}$ and $21^{\text {st }}$ centuries in the sphere of food consumption. These changes are connected with new models of consumer behaviour becoming widespread. Analysis of the level and structures of food consumption in the spatial perspective, i.e. between countries in the world, shows the process of consumption homogenization. Patterns of consumerism are supported by: the development of commercial international networks, offer standardization by shopping centres, media, especially television, including programs emitted by commercial stations, the development and spread of the Internet, wireless telecommunications, as well as the development of fast food restaurant networks, the popularization of "instant" food (semi-finished products, ready dishes, food concentrates, sauces, instant soup and chips, bars of chocolate), the mass development of tourism supporting the exchange of consumption models between tourists and the local population, as well as dietary recommendations leading to rational maintaining (Kwasek, 2010). Assimilation of inappropriate standards of food consumption has an adverse influence on life and the public health.

Research confirms that the quality of foodstuffs and the way of feeding have a direct influence on the population's health. Meanwhile, changes in lifestyle cause that food consumption in the developed countries, also in the European Union, is unfortunately directed at worse quality food (FAO, 2010). What's more, it is leading to food spoiling and strengthening negative trends in consumption. Increase of consumption, and at the same time increase in supply of food, is unfortunately affecting the worsening of the food quality. Mass production unavoidably causes the adulteration of final goods and also supports a cut in price. This is an additional incentive inducing many consumers to shop. The alternative to the mass manufacture of foodstuffs could be production using environmental methods in organic farms.

The main goal of the research was verification of the hypothesis that the quality of food is better if the food is produced in regions with a large scale of protected areas.

\section{Data sources}

Main source of data used in the paper are data from Statistical Yearbooks of Agriculture in Poland and EU, reports relating to organic farming, data from the Central Statistical Office in Poland concerning rural areas and environment in Poland.

It shows that production using environmental methods (fruits and vegetables, milk, meat, poultry and eggs) in combination with clean production technologies, tradition, knowledge and experience of entrepreneurs can contribute to the improvement of food quality. Strengthening cooperation between the producers of environmentallyfriendly products and the food processing industry workers will cause an increase in food quality. Development of organic farming will force the development of organic processing to work in accordance with the requirements of environmental protection. 
The local food processing plants that use the appropriate quality of raw materials will contribute to the better quality of the final products of production.

The base of organic farming development, apart from the necessity to care for the natural environment, is the increase in demand for healthy food. Thus far, this is noticeable above all on the European Union markets, where - what should be emphasized - the prices of organic products are much higher than that of remaining products. In spite of this, consumer spending on organic food is constantly growing.

In 2008, the global market for certified organic food and drinks was estimated to be 34.8 billion Euros. The countries with the highest per capita consumption in 2008 were Denmark (annual per capita consumption 132 Euros), Switzerland (119 Euros) and Austria (97 Euros). The countries with the highest shares of organic food sales in 2008 were also Denmark (6.7\% market share), Austria (5.3\%) and Switzerland (4.9\%). In 2009, the market continued to grow in most countries: Denmark reached a marked share of $7.2 \%$, Austria $6 \%$, Switzerland 5.3\% (Organic Agriculture Worldwide, 2011). Research shows that despite the global crisis in 2008, the demand for organic products increased. Thirty-four percent (34\%) of respondents are regularly buying environmentally-friendly products (32\% in 2007) and $24 \%$ of those surveyed is prone to pay more for environmentally-friendly products $(20 \%$ in 2007). Inhabitants of the European Union are the most conscious consumers. Research shows that $54 \%$ of the inhabitants of the EU are inclined to pay a minimum of $5 \%$ more for an environment-friendly product. Only $19 \%$ of respondents do not want to pay more for environmentally-friendly products (Manget, Roche, Münnich, 2009).

In Poland, the market of organic foodstuffs, in spite of predicted growth, is still proportionally marginal. One should seek causes e.g. in high prices compared with conventional food. Therefore, the organic products market is narrowed to specialist shops, which are located in large urban agglomerations. This situation discourages the producers. They need to use agent services and as a result, the price they receive for environmentally-friendly products is the same as the price for traditional products. Only producers who provide healthy food directly to shops receive higher prices. It should be emphasized that the quality of food depends directly on the quality of the natural environment. A clean atmosphere, water and uncontaminated soil can only have a positive influence on food production.

\section{Materials and Methods}

The paper based on comparative analysis of the Polish voivodships with large and small shares of valuable natural areas in the total area of the voivodship in relation to the ecological farms and eco-friendly food processing plants. Data used in the analysis was taken from the Central Statistical Office in Poland and European Union Reports. The author has compared voivodships, in which protected areas are dominating, with the quantity of organic farms and eco-friendly food processing plants functioning in these voivodships.

An area of $32.3 \%$ of Poland is under legal protection (the Central Statistical Office, 2012). There are 23 national parks, 121 landscape parks, 384 protected landscape areas and 1451 
reserves (the Central Statistical Office, 2012). The main function of valuable natural areas is maintaining the advantages of the natural environment in an undisturbed state. The condition of running business activity on this type of area is to not destroy the natural state. Model forms of business activity possible to carry out on such areas are organic agriculture and ecological food processing.

The organic farming sector is characterized by a great increase in the quantities of agricultural farms offering environmentally-friendly products in the last ten years. This is a worldwide tendency. However Australia and Oceania, Europe and the dynamically growing market of South America are playing the dominant role. In Europe, the countries with the highest participation of organic farming in the total farming sector in 2009 were Liechtenstein (26.87\%), Austria (18.50\%), Sweden (12.56\%), Switzerland (10.78\%) and Estonia (10.49\%). In Poland, the participation of organic farming in total farming was $2.37 \%$. The largest area of cultivated land as organic farming was in Spain (1 330774 ha), Italy (1 $106684 \mathrm{ha}$ ) and Germany (947 $115 \mathrm{ha}$ ). Poland was at $9^{\text {th }}$ place amongst countries with the biggest area cultivated as ecological farms in Europe. The area of ecological cultivations in Poland in 2009 was 367062 ha (Organic Agriculture Worldwide, 2011). The total organic area is the sum of the areas under conversion and the fully converted areas. The areas under conversion as a percentage of the total organic area can give an indication of the potential growth in the organic sector in the years to come. In 2008, there were 4 countries whose share exceeded 40\%: Poland (43.1\%), Spain (47.6\%), Romania (48.9\%) and Bulgaria (74.6\%), (Rohner Thielen, 2010). In Poland, as well as in the other countries of the European Union, the number of organic farms is increasing. There were 10153 ecofriendly farms with the relevant certificate and 6938 farms under conversion in 2009. In 2010 the number of certified farms was 12901 (more details in the table below).

Table 1. Increase in organic farms in Poland (2002-2010)

\begin{tabular}{|c|r|r|r|r|}
\hline \multirow{2}{*}{ Years } & \multicolumn{3}{|c|}{ Certified } & \multicolumn{2}{c|}{ Under conversion } \\
\cline { 2 - 5 } & Farms & Agricultural area in ha & Farms & Agricultural area in ha \\
\hline 2002 & 882 & 20862 & 1095 & 22966 \\
\hline 2005 & 1951 & 37492 & 5231 & 122218 \\
\hline 2007 & 6618 & 137891 & 5252 & 149638 \\
\hline 2008 & 8685 & 178732 & 6211 & 136116 \\
\hline 2009 & 10153 & 222022 & 6938 & 145040 \\
\hline 2010 & 12901 & 308095 & 7681 & 210974 \\
\hline
\end{tabular}

Source: Statistical Yearbook of Agriculture 2011, Branch Yearbooks, the Central Statistical Office, Warsaw 2012, p. 100.

Strong interest in environmentally friendly products caused that the number of organic farms in 2010 was fourteen times higher than in 2002 . About $60 \%$ of all organic farms has certificates (12 901) and 7681 are under conversion. 
Picture 1. Map of voivodships in Poland

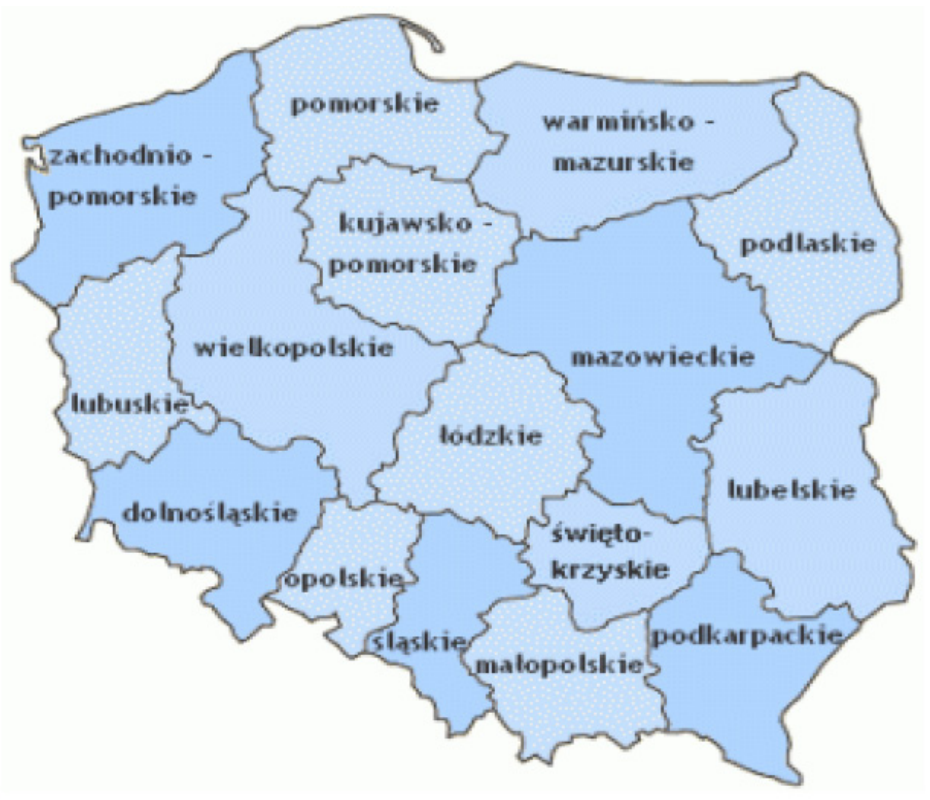

Source: Central Statistical Office, http://www.stat.gov.pl

In the comparison of voivodships, the largest number of organic farms is in the voivodships: Malopolskie (2197), Podkarpackie (2014), Lubelskie (1710), Zachodniopomorskie (1696) and Mazowieckie (1673). In the arrangement of voivodships in 2010, the largest number of organic farms in total was recorded in the voivodships of Malopolskie (2197), Podkarpackie (2014), Lubelski (1710), Zachodniopomorskie (1696) and Mazowieckie (1673).

These voivodships concentrated over $54 \%$ of organic farms in the country (the Central Statistical Office, 2012).

Comparing all voivodships in Poland, one should notice that in the "Green Voivodships", i.e. with a high share of protected areas in the total area, the quantity of organic farms is larger. It is often emphasized that valuable natural areas support the development of this form of business activity.

Table 2. Protected areas and the quantity of organic farms in all voivodships in Poland (2009)

\begin{tabular}{|l|r|r|r|r|}
\hline \multicolumn{1}{|c|}{ Voivodships } & $\begin{array}{c}\text { Share of protected areas } \\
-\% \text { in the total area }\end{array}$ & $\begin{array}{c}\text { Rank in } \\
\text { Poland }\end{array}$ & $\begin{array}{c}\text { Number of } \\
\text { organic farms }\end{array}$ & $\begin{array}{c}\text { Rank in } \\
\text { Poland }\end{array}$ \\
\hline Poland & 32.3 & & 17091 & \\
\hline Dolnoślaskie & 18.2 & 16 & 1021 & 9 \\
\hline Kujawsko-pomorskie & 31.3 & 9 & 279 & 14 \\
\hline Lubelskie & 22.7 & 12 & 1710 & 3 \\
\hline Lubuskie & 38.9 & 5 & 579 & 11 \\
\hline
\end{tabular}




\begin{tabular}{|l|r|r|r|r|}
\hline \multicolumn{1}{|c|}{ Voivodships } & $\begin{array}{c}\text { Share of protected areas } \\
-\% \text { in the total area }\end{array}$ & $\begin{array}{c}\text { Rank in } \\
\text { Poland }\end{array}$ & $\begin{array}{c}\text { Number of } \\
\text { organic farms }\end{array}$ & $\begin{array}{c}\text { Rank in } \\
\text { Poland }\end{array}$ \\
\hline Łódzkie & 18.8 & 15 & 366 & 13 \\
\hline Małopolskie & 52.1 & 2 & 2197 & 1 \\
\hline Mazowieckie & 29.7 & 10 & 1673 & 5 \\
\hline Opolskie & 27.3 & 11 & 63 & 16 \\
\hline Podkarpackie & 44.5 & 4 & 2014 & 2 \\
\hline Podlaskie & 32.0 & 7 & 1528 & 6 \\
\hline Pomorskie & 32.7 & 6 & 494 & 12 \\
\hline Śląskie & 22.1 & 13 & 199 & 15 \\
\hline Świętokrzyskie & 64.6 & 1 & 1170 & 8 \\
\hline Warmiańsko-mazurskie & 46.5 & 3 & 1514 & 7 \\
\hline Wielkopolskie & 31.8 & 8 & 588 & 10 \\
\hline Zachodniopomorskie & 21.1 & 14 & 1696 & 4 \\
\hline
\end{tabular}

Source: own research on the base of Environment 2010; Statistical Yearbook of Agriculture 2011.

The table 2 shows that the "Green Voivodships" are Swietokrzyskie, Malopolskie, Warminsko-mazurskie and Podkarpackie. There are 6895 organic farms, more than 40\% of all organic farms in Poland, in these 4 voivodships. Voivodships with a small share of protected areas in the total area are Dolnoslaskie, Lodzkie, Zachodniopomorskie and Slaskie. Three thousand two hundred and eighty-two (3 282) organic farms, less than 20\% of all organic farms in the country, function there.

Regions in which the quantity of ecological farms in 2009 was the highest are Malopolskie, Podkarpackie and Lubelskie Voivodships. The voivodship that was leading in the field of health food production in 2009 was the Malopolskie Voivodship. In 2009, 2197 organic farms functioned there. This voivodship is also characterized by a large share of protected areas in the total area. Over 52\% of the Malopolskie Voivodship is under legal protection. The Podkarpackie is the next voivodship playing a great role in ecological food production, with 2014 organic farms. Just as in the case of the Malopolskie Voivodship, in the Podkarpackie the valuable natural areas occupy a considerable part of this area (over $44 \%$ of the voivodship is under legal protection).

The third rank in terms of the number of organic farms in Poland is the Lubelskie Voivodship (1710 organic farms in 2009). This voivodship is not situated in a part of Poland with many protected areas. There are less than $22 \%$ of valuable natural areas. Nevertheless, the rapid development of eco-friendly farms is determined by the typically agricultural character of this region. The economy of the voivodship is based on farming and the Lubelskie Voivodship is leading in the field of agricultural and fruit cultivations. Production of healthy food is dynamically developing in this area.

In 2009, the Slaskie and Opolskie Voivodships were characterized by a low figure of ecofriendly farms (199 and 62, respectively). The share of protected areas in the total area of the above-mentioned voivodships is relatively insignificant (rank 11 and 13 for 16 voivodships in Poland). 
Amongst products cultivated on organic farms, fruits and vegetables dominate. Comparing all countries of the European Union, one should state that Poland is a major producer and supplier to the Euromarket. The share of vegetables produced in Poland in the total production of the European Union is over 25\%. Minimally more is produced only in Romania. However, the share of fruits is $21.5 \%$, which gives Poland the $1^{\text {st }}$ place in the European Union (Martinez Palou, Rohner Thielen 2008).

The development of organic farming should be a specialty and a chance of the dynamic development of agriculture on protected areas. The advantages of nature are undoubtedly an additional determinant of the regional development and a factor influencing the appropriate food quality. The natural environment determines agricultural production and the state of the environment could have a positive influence on the quality of vegetables, fruits, meat, milk and poultry.

The second group of business entities affecting the food quality are eco-friendly food processing plants. Similarly as in the case of organic farms, the last years are characterized by great dynamics of increase in eco-friendly food processing plants in Poland.

Table 3. The number of eco-friendly food processing plants in Poland (2004-2009)

\begin{tabular}{|l|r|}
\hline Years & \multicolumn{2}{|c|}{ Food processing plants } \\
\hline 2004 & 55 \\
\hline 2005 & 99 \\
\hline 2006 & 170 \\
\hline 2007 & 206 \\
\hline 2008 & 236 \\
\hline 2009 & 277 \\
\hline
\end{tabular}

Source: own research on the base of Organic farming in Poland. Report 2007-2008, date IJHARS.

Data in the table 3 shows that year 2004-2009 were characterized by an increase in the number of eco-friendly food processing plants, which confirms the dynamic development of the organic sector of production in Poland. In 2009, 277 eco-friendly food processing plants were operating in Poland. However their location is not a consequence of organic farms' localization. Therefore, the activity of eco-friendly food processing plants is not entirely consistent with organic farms' activity. The relation between the protected natural areas and the quantity of eco-friendly food processing plants within the given area is shown in the table 4. 
Table 4. Protected natural areas and the number of eco-friendly food processing plants within the voivodships in Poland (2009)

\begin{tabular}{|l|r|r|r|r|}
\hline \multicolumn{1}{|c|}{ Voivodship } & $\begin{array}{c}\text { Share of protected areas - } \\
\text { \% in the total area }\end{array}$ & $\begin{array}{c}\text { Rank in } \\
\text { Poland }\end{array}$ & $\begin{array}{c}\text { Number of eco-friendly } \\
\text { food processing plants }\end{array}$ & $\begin{array}{c}\text { Rank in } \\
\text { Poland }\end{array}$ \\
\hline Poland & 32.3 & 277 & 11 \\
\hline Dolnośląskie & 18.2 & 16 & 13 & 8 \\
\hline Kujawsko-pomorskie & 31.3 & 9 & 35 & 3 \\
\hline Lubelskie & 22.7 & 12 & 6 & 14 \\
\hline Lubuskie & 38.9 & 5 & 14 & 7 \\
\hline Lódzkie & 18.8 & 15 & 20 & 5 \\
\hline Małopolskie & 52.1 & 2 & 54 & 1 \\
\hline Mazowieckie & 29.7 & 10 & 1 & 16 \\
\hline Opolskie & 27.3 & 11 & 24 & 4 \\
\hline Podkarpackie & 44.5 & 4 & 5 & 15 \\
\hline Podlaskie & 32.0 & 7 & 10 & 11 \\
\hline Pomorskie & 32.7 & 6 & 12 & 9 \\
\hline Śląskie & 22.1 & 13 & 8 & 13 \\
\hline Śiętokrzyskie & 64.6 & 1 & 9 & 12 \\
\hline Warmiańsko-mazurskie & 46.5 & 3 & 36 & 2 \\
\hline Wielkopolskie & 31.8 & 8 & 19 & 6 \\
\hline Zachodniopomorskie & 21.1 & 14 & & 2 \\
\hline
\end{tabular}

Source: own research on the base of Environment 2012; Statistical Yearbook of Agriculture 2011.

In the case of eco-friendly food processing plants, dependence between their number and the state of the natural environment does not appear. In the "Green Voivodships" (Swietokrzyskie, Malopolskie, Warminsko-mazurskie, Podkarpackie) 61 eco-friendly food processing plants operate, that is $22 \%$ of all food processing plants of this type in Poland. In these voivodships, on average 113 organic farms falls on one food processing plant.

Regions where the number of eco-friendly food processing plants was the highest in 2009 are the Mazowieckie (54), Wielkopolskie (36) and Lubelskie (35) Voivodships. A high share of valuable natural areas in the total area does not characterize these voivodships. These voivodships aren't regions (outside the Lubelskie Voivodship) where the production of organic food is the highest. This divergence confirms that food processing plants probably acquire the raw materials from the neighbouring regions. Transport of the raw material that was produced using environmental methods can have a negative impact on the final quality. It seems that the solution is the proper localization of eco-friendly food processing plants, which should be close to organic farms.

Environmentally-friendly products are produced by organic farms which are mainly located in areas with many protected areas. The natural environment has a beneficial influence on the quality of the raw materials. However, the quantity of organic farms is not a determinant of the number of food processing plants located within the given voivodship. The Podlaskie Voivodship with many valuable natural areas is a good example. There are only 5 eco-friendly food processing plants and 1528 organic farms, so the ecologically produced raw material is probably processed in other voivodships, 
which makes the quality of the final product worse.

\section{Results and Discussion}

Analysing the branches in ecological processing, one should state that the processing of fruits and vegetables dominates. A large share in the processing of organic products in 2007 was had by the processing of fruits and vegetables $-28 \%$ and cereal $-19 \%$. Meat production and processing had a smaller share $-7 \%$, as well as the production of dairy products $-3 \%$. In 2008 (with reference to the previous year), a reduction of the share of fruits, vegetables, cereal and meat processing took place. The share of fruits and vegetables processing was $25 \%$, cereal $13 \%$, and meats $5 \%$. Production of other foodstuffs (for example sugar, cocoa, chocolate, tea, coffee, spices and ready dishes) determined $27 \%$ of the total food processing industry in organic farming (IJHARS, 2009).

Figure 1. Branch share in ecological food processing in Poland (2008)

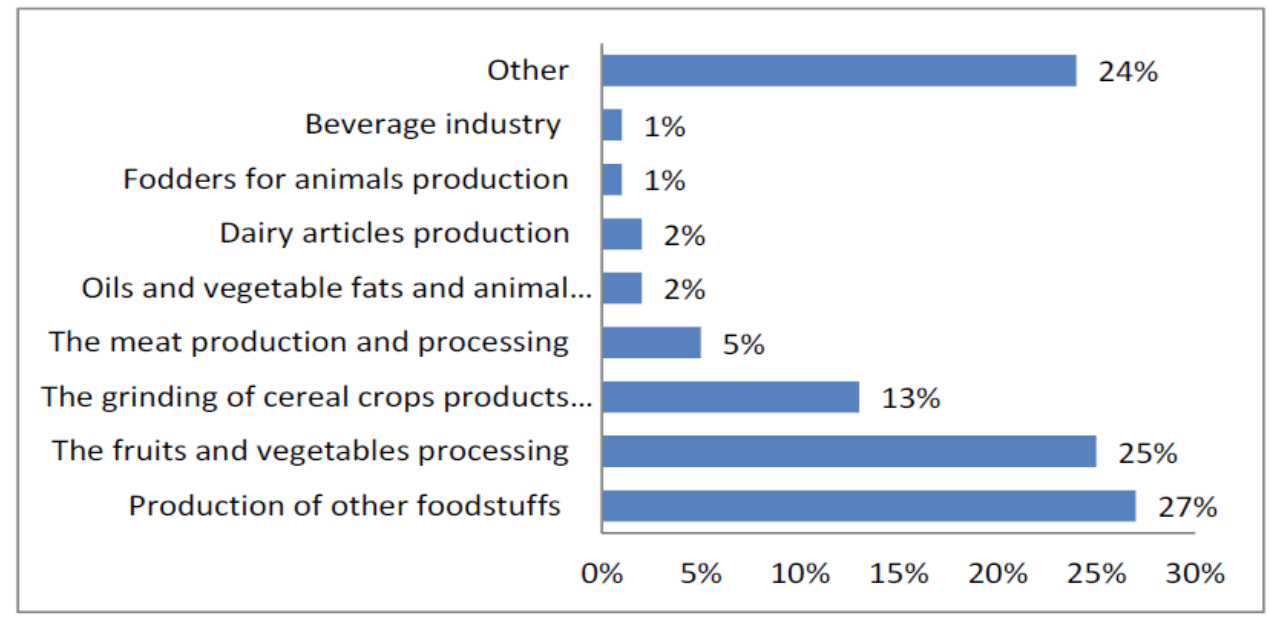

Source: Organic farming in Poland, 2009, IJHARS.

The data above (Figure 1.) show that one of the dominating branches in ecological processing is fruits and vegetables processing. In the European Union, Poland is the leader in the field of fruits and vegetables processing. Data show that vegetables production in Poland is over $25 \%$ and fruit production is over $21 \%$ of the internal EU market. This is the causes of the large number of fruit and vegetable processing companies.

Fruits and vegetables are raw materials that spoil easily and quickly, which affects the quality of the final products. In this case, proper storage and fast and efficient transport are very important. The distant localization of eco-friendly food processing plants from the producers of vegetables and fruits can adversely affect the quality of the produced food. In the end, good quality of the produced raw material on valuable natural areas is not a determinant of high food quality. Inappropriate storage and transport of high quality ecological raw materials can greatly worsen the quality of the final product. Another factor adversely affecting the food quality produced from the organic raw materials is the 
low number of eco-friendly food processing plants located close to the producers. The correlation between the quantity of organic farms and the number of eco-friendly food processing plants is shown in the table 5 .

Table 5. Relation between the quantity of organic farms and the number of eco-friendly food processing plants in a given voivodships in Poland (2009)

\begin{tabular}{|l|r|r|r|}
\hline \multicolumn{1}{|c|}{ Voivodship } & \multicolumn{1}{c|}{$\begin{array}{c}\text { Number of } \\
\text { organic farms }\end{array}$} & $\begin{array}{c}\text { Number of eco- } \\
\text { friendly food } \\
\text { processing plants }\end{array}$ & $\begin{array}{c}\text { Number of organic farms / } \\
\text { Number of eco-friendly food } \\
\text { processing plants }\end{array}$ \\
\hline Dolnośląskie & 1021 & 11 & 92.81818 \\
\hline Kujawsko-pomorskie & 279 & 13 & 21.46154 \\
\hline Lubelskie & 1710 & 35 & 48.85714 \\
\hline Lubuskie & 579 & 6 & 96.5 \\
\hline Łódzkie & 366 & 14 & 26.14286 \\
\hline Małopolskie & 2197 & 20 & $109.85 *$ \\
\hline Mazowieckie & 1673 & 54 & 30.98148 \\
\hline Opolskie & 63 & 1 & 63 \\
\hline Podkarpackie & 2014 & 24 & $30.91667 *$ \\
\hline Podlaskie & 1528 & 5 & 405.6 \\
\hline Pomorskie & 494 & 10 & 16.5 \\
\hline Śląskie & 199 & 12 & $146.25 *$ \\
\hline Świętokrzyskie & 1170 & 8 & $168.2222 *$ \\
\hline Warmiańsko-mazurskie & 1514 & 96 & 89.33333 \\
\hline Wielkopolskie & 588 & 19 & 89,26316 \\
\hline Zachodniopomorskie & 1696 & & \\
\hline
\end{tabular}

* Voivodships with a large share of valuable natural areas in the total area.

Source: own research

In the "Green Voivodships" the indicator of the number of organic farms to the number of eco-friendly food processing plants is the least beneficial, i.e. the number of food processing plants is the lowest in relation to the number of organic farms. It can be seen that in the Podlaskie, Warminsko-mazurskie, Swietokrzyskie and Malopolskie voivodships there is a ratio of one eco-friendly food processing plant to over 100 organic farms. The worst situation is in the Podlaskie Voivodship, where the ratio is one eco-friendly food-processing plant to over 300 organic farms.

The argument justifying the presence of more eco-friendly food-processing plants in relation to the quantity of organic farms within the voivodships, where the share of protected areas is smaller, could be the barriers associated with the location of food-processing plants. Unfortunately, the inhabitants and the local authorities could still consider valuable natural areas a barrier for the localization of industrial plants, which also include ecological processing plants. Meanwhile, ecological trends cause that businesses are interested in applying solutions to not have a negative impact on the environment. 


\section{Conclusion}

To sum up, it is possible to state that an increase in demand for environmentally-friendly products clearly translates into interest in this form of production. In Poland, the area of ecological cultivations is constantly increasing. This trend should have a positive effect on organic farming development in valuable natural areas. There is a correlation between the state of the natural environment and the quantity of organic farms in a given voivodship. The case study of Poland confirms it. There are more organic farms in the voivodships with a large share of valuable natural areas in the total area than in regions where the share of protected areas is smaller. Nevertheless, it is not the only factor affecting the transformation of arable farms into ones producing exclusively health food. A large share of protected areas in the total area does not affect the number of eco-friendly food processing plants. The relation is simply the opposite, that is in the "Green Voivodships" in spite of the bulk of organic farms, there are less food processing plants. The distant localization of eco-friendly food processing plants can adversely affect the quality of the produced food. In the end, the good quality of the raw materials produced on protected areas does not necessarily translate to a high food quality.

The verification of the hypothesis that the food quality is better when it is produced in regions with a large share of protected areas is ambiguous. The protected areas affect the quality of the raw materials produced on organic farms. The state of the natural environment has a beneficial influence on setting up new organic farms. However, ecological processing, in most cases, is not located in protected areas, in other words close to the organic farms. This in turn could cause inappropriate food storage and transport, which could have an adverse impact on the quality of the final product.

\section{Literature}

1. FAO (2010): Guide for decision makers for farmer organizations and exporters wishing to export organic and fair-trade certified products and for business support organizations, Food and Agriculture Organization of the United Nations, Rome, Italy.

2. IJHARS (2009): Organic farming in Poland, Report 2007-2008, Warsaw, Poland.

3. Kwasek, M. (2010): Economic and social tendencies in food consumption in European Union countries, Institute of Agriculture and Food Economics National Research Institute, Report nr 180, Warsaw, Poland.

4. Manget, J., Roche, C., Münnich, F. (2009): Report capturing the green advantage for consumer companies, the Boston Consulting Group, Boston, USA.

5. Martinez Palou,A., Rohner Thielen, E. (2008): Fruit and vegetables: fresh and healthy on European tables, Statistics in focus, vol. 60, no. 3-4.

6. Ministry of Agriculture and Rural Development (2011): Rolnictwo ekologiczne, available at: http://www.minrol.gov.pl/pol/Jakosc-zywnosci/Rolnictwo-ekologiczne/

7. Organic Agriculture Worldwide (2011): The World of Organic Agriculture, available 
at: http://www.organic-world.net/fileadmin/documents/Common-contents/publications/ schaack-2010-biofach.pdf

8. Rohner Thielen, E. (2010): Area under organic farming increased by 7.4\% between 2007 and 2008 in the EU-27, Statistics in focus, vol. 10, no. 3.

9. The Central Statistical Office (2012): Environment, Warsaw, Poland.

10. The Central Statistical Office (2012): Rural areas in Poland, Warsaw Olsztyn, Poland.

11. The Central Statistical Office (2012): Statistical Yearbook of Agriculture 2011, Warsaw, Poland. 